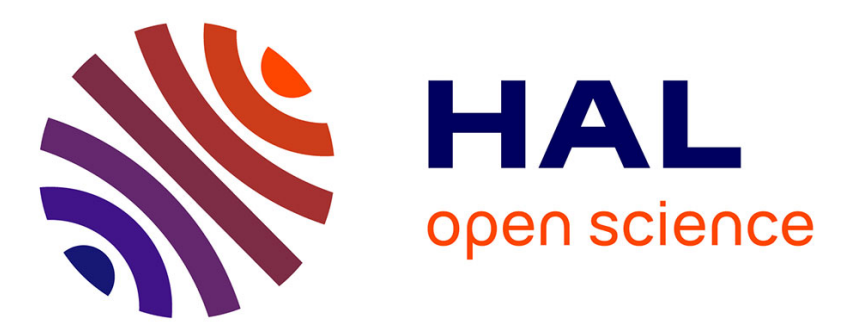

\title{
Biodiversity as a barrier to glioma cell invasion.
}

Laurent Selek, Franck Mauconduit, Marie-France Nissou, Guillaume Nugue, Hana Lahrech, François Berger, Pascal Mossuz, Didier Wion

\section{To cite this version:}

Laurent Selek, Franck Mauconduit, Marie-France Nissou, Guillaume Nugue, Hana Lahrech, et al.. Biodiversity as a barrier to glioma cell invasion.. Medical Hypotheses, 2012, 78 (4), pp.459-61. 10.1016/j.mehy.2012.01.005 . inserm-00733968

\section{HAL Id: inserm-00733968 https://www.hal.inserm.fr/inserm-00733968}

Submitted on 20 Sep 2012

HAL is a multi-disciplinary open access archive for the deposit and dissemination of scientific research documents, whether they are published or not. The documents may come from teaching and research institutions in France or abroad, or from public or private research centers.
L'archive ouverte pluridisciplinaire HAL, est destinée au dépôt et à la diffusion de documents scientifiques de niveau recherche, publiés ou non, émanant des établissements d'enseignement et de recherche français ou étrangers, des laboratoires publics ou privés. 


\title{
Biodiversity as a barrier to glioma cell invasion.
}

\author{
Laurent Selek ${ }^{1}$ (MD, PhD), Franck Mauconduit ${ }^{2}$ (MS), Marie-France Nissou $^{2}$ (MS), Guillaume \\ Nugue $^{2}$ (MS), Hana Lahrech ${ }^{2}$ (PhD), François Berger ${ }^{2}$ (MD, PhD), Pascal Mossuz ${ }^{3 *}$ (MD, PhD) \\ and Didier Wion ${ }^{2 * q}$ (PhD). \\ Department of Neurosurgery, University Hospital Centre, Grenoble, France ; INSERM U836, \\ ${ }^{2}$ Grenoble Institut des Neurosciences, Université Joseph Fourier, University Hospital Centre, \\ Bâtiment E.J. Safra, 38042 Grenoble, France. ${ }^{3}$ Department of Clinical Onco-Hematology, \\ University Hospital Centre, 38042 Grenoble, France.
}

*equal contribution

"corresponding author: didier.wion@ujf-grenoble.fr

\begin{abstract}
Gliomas are extremely aggressive and lethal forms of brain cancer. Unlike many other cancer types, glioma cells rarely metastasize. They spread throughout the brain and invasiveness of glioma cells is a major cause of therapeutic failure. In plant ecosystem, biodiversity acts locally as a barrier to ecological invasion. By analogy, we hypothesize that the low cell diversity of differentiated tissues, a counterpart of their functional efficiency, opens the way to local cancer cell invasion. Seeding the brain tumor microenvironment with heterogeneous cell populations could be a mean to limit cancer cell invasion by enhancing cell biodiversity.
\end{abstract}

\section{Introduction.}

Tumor progression represents the co-evolution of tumor cells with their microenvironment $[1,2,3]$. The idea that cancer cells behave as plant or animal invading an ecosystem is not new. Making the invaded habitat less hospitable has proven effective with invasive plants and animals. By analogy with ecosystems where introducing novel species can lead to coexistence or extinction, it can be hypothesized that the deliberate implantation in the tumor microenvironment of cells issued from a different organ will change many environmental parameters simultaneously, including $\mathrm{pH}, \mathrm{pO}$, nutrients, cytokine networks, extra-cellular matrix. These changes could in turn alter locally the course of tumor progression either positively or negatively. Accordingly, the implantation of a cell population exhibiting a higher proliferation rate than cancer cells and dedicated to out-compete cancer cells for available resources has been proposed as a therapeutic option [4]. Likewise cancer 
cell therapy approaches in which engineered cells acts as cancer cells predators have been proposed $[5,6,7]$.

Hypothesis: Our hypothesis is that the low cell biodiversity of differentiated organs favors the local invasion of cancer cells. This hypothesis originates from plant studies demonstrating that biodiversity can act as a barrier to ecological invasion [8]. Therefore, increasing the biodiversity of the tissue where tumor develops by the local implantation of cells issued from other tissues would represent a line of defense against the spread of invading cancer cells. A notable point is that therapeutic implanted cells do not target cancer cells. They act by "buffering" cancer cell invasion through the increase in cell diversity of the ecosystem. This point is critical. Most cancer therapies are dedicated to target cancer cells. However, this quest for specificity might be paradoxically a drawback. Because of cancer cells heterogeneity and plasticity, no one targeted therapy can be the best one for all the cancer cells present in a given patient. On the contrary, increasing the biodiversity of tissues does not target a special cancer cell population directly but rather the cancer ecosystem. From a mechanistic point of view, one possible explanation can be that, as reported with plant ecosystems [9], increasing the ecosystem diversity uniformly lowers the levels of resources. Hence, this kind of approach could limit the emergence of therapeutic resistant cancer cell populations. In the proposed model, the local increase in biodiversity due to implantation of heterogeneous cell populations exceeds the cancer cell variability potential. This in turn, will limit both tumor growth and the successful recruitment of cancer variants.

\section{How the hypothesis could be evaluated}

To illustrate how can be tested the hypothesis that increasing tissue cell biodiversity hampers tumor growth, we propose to use a brain tumor experimental model. Gliomas, are brain tumors for which no curative therapy exists and whose growth is restricted to the brain. Because glioma cells do not metastasize, survival is directly linked to the local control of the disease. This unique biotope provides the opportunity to investigate how brain tumor ecosystem can be perturbed when cell biodiversity increases. Moreover, implanting cells in the brain is relatively easy due to the size of this organ. An additional advantage of this model is that the follow up of the tumor is amenable in vivo by Magentic Resonnance Imaging (MRI) which is able to localize and measure the size of the tumor using GD-DOTA a paramagnetic contrast agent.

To demonstrate how the hypothesis could be tested, a pilot experiment was performed. In the suggested experimental approach $5.10^{4}$ human glioma cells [10] were implanted in the brain of nude mice and tumor growth was assessed 30 days later by MRI (Fig 1 A-D). Then, the biodiversity of brain 
tissue was increased by injecting 5. $10^{6}$ cells issued from a special type of bone marrow cells expanded in culture named Dexter's culture [11] inside and around the tumor mass. Cells issued from Dexter cultures were choose to generate biodiversity because i) they are heterogeneous cell cultures from bone marrow including fibroblasts, macrophages, adipocytes, endothelial cells, mesenchymal stem. ii) Dexter cells secrete cytokines and components of the extracellular matrix such as fibronectin, laminin and collagen which also participate to the biodiversity of the microenvironment; iii) they are able to generate additional biodiversity as they contain multipotent mesenchymal stem cells which have the ability to differentiate into multiple cell types including osteoblasts, chondrocytes, myoblasts, adipocytes and neurons [12] and; iv) bone marrow cells are naturally challenged in vivo to both normoxic and hypoxic microenvironments [13], a situation also encountered in the glioma microenvironment. Thirty days after bone marrow stromal cells grafting, (that is sixty days after glioma cells implantation), tumor growth can be evaluated by MRI (Fig. 1). This pilot experiment demonstrates the feasibility of testing the role of increasing cell biodiversity on tumor growth with this kind of experimental model. Interestingly, MRI imaging showed that cell implantation could limit the progression of the disease (Fig. 1 C,D) compared to control animals (Fig 1. A,B). However, although we noticed a small general positive effect on the overall survival in Dexter cells treated mouse (Fig. 1E), the effect was statistically non significant $(p<0.06)$. This suggests the interest of testing additional cell mixtures.

\section{Discussion.}

Because glioma cells rarely metastasize their infiltration into brain parenchyma is a major cause for brain tumor therapeutic failure. Although, this propensity of invasiveness is an intrinsic feature of cancer cells, extrinsic ecological factors related to the tumor microenvironment are also involved. Another feature of glioma is intratumoral cancer cell heterogeneity, a major obstacle to the design of targeted therapies. This is the consequence of the fact that tumor cells evolve during the course of the disease in response to selection pressure generated both by the changing tumor microenvironment and by radio- or chemotherapies. Glioma grows because glioma cells establish permissive cell-to-cell interactions with neurons, microglia, glial cells, and vascular and peripheral immune cells. Here, we propose to fight glioma by generating in the tumor environment a higher level of cell biodiversity exceeding the evolutionary and adaptive potential of cancer cells. The pilot experiment presented here demonstrates how the hypothesis can be tested. The therapeutic effect will depend on the overall number of implanted cells but also on the combinations of the different cell types used and on the time and frequency of cell implantation. We are aware that some cell mixes will have adverse effects and will facilitate invasion by promoting the tumor ecosystem functioning, but other cell combinations should contribute to invasion resistance. Thus, both cell 
diversity and cell composition are important. In brain, invasion routes used by glioma cells include myelinated axons and blood vessels. Cells able to occupy these migratory tracks are therefore good candidates. A notable interest of this therapeutic approach which can be viewed as an "ecological therapy" [3], is that the local increase in cell biodiversity can be done by autologous grafting. A possible drawback is that such local therapy could have a limited interest for metastasic tumors. Determining which can be the therapeutically more efficient cell formulation will require an extensive prospective work. The continuation of this work depends to the vagaries of the funding process. Should that process be unfavorable, it may take several years before we can test more thoroughly the hypothesis that in glioma a great increase in cell diversity lowers local tumor growth rate, and to determine which cell mixtures are the most efficient. The deadly nature of glioma justifies that this hypothesis will be rapidly tested.

\section{Conflict of interest. Authors report no conflict of interest.}

[1] B. Crespi and K. Summers, Evolutionary biology of cancer, Trends Ecol Evol 20 (2005), pp. 545-552.

[2] L.Merlo, J.W. Pepper, B.J. Reid and C.C. Maley, Cancer as an evolutionary and ecological process, Nat Rev Cancer 6 (2006), pp. 924-935.

[3] K.J. Pienta, N. McGregor, R. Axelrod and D.E. Axelrod, Ecological therapy for cancer: defining tumors using an ecosystem paradigm suggests new opportunities for novel cancer treatments, Transl Oncol 1 (2008), pp. 158-164.

[4] T.S. Deisboeck and Z. Wang, A new concept for cancer therapy: out-competing the aggressor, Cancer Cell Int 8 (2008), p. 19.

[5] S. Benedetti, B. Pirola, B. Pollo, L. Magrassi, M.G. Bruzzone, D. Rigamonti, et al., Gene therapy of experimental brain tumors using neural progenitor cells, Nat Med 6 (2000), pp. 447-450.

[6] K.S. Aboody, A. Brown, N.G. Rainov, K.A. Bower, S. Liu, W. Yang, et al., Neural stem cells display extensive tropism for pathology in adult brain: evidence from intracranial gliomas, Proc Natl Acad Sci U S A 97 (2000), pp. 12846-12851.

[7] K. Nakamura, Y. Ito, Y. Kawano, K. Kurozumi, M. Kobune, H. Tsuda, et al., Antitumor effect of genetically engineered mesenchymal stem cells in a rat glioma model, Gene Ther 11 (2004), pp. 1155-1164.

[8] T.A. Kennedy, S. Naeem, K.M. Howe, J.M. Knops, D. Tilman and P. Reich, Biodiversity as a barrier to ecological invasion, Nature 417 (2002), pp. 636-638

[9] D. Tilman, Niche tradeoffs, neutrality, and community structure: a stochastic theory of resource competition, invasion, and community assembly, Proc Natl Acad Sci U S A 101 (2004), pp. 10854-10861.

[10] N. Platet, S.Y. Liu, M.E. Atifi, L. Oliver, F.M. Vallette, F. Berger, et al., Influence of oxygen tension on CD133 phenotype in human glioma cell cultures, Cancer Lett 258 (2007), pp. 286290.

[11] T.M. Dexter, T.D. Allen and L.G. Lajtha, Conditions controlling the proliferation of haemopoietic stem cells in vitro, J Cell Physiol 91 (1977), pp. 335-344.

[12] Z.J. Liu, Y. Zhuge and O.C. Velazquez, Trafficking and differentiation of mesenchymal stem cells, J Cell Biochem 106 (2009), pp. 984-991. 
[13] A.V. Guitart, M. Hammoud, P. Dello Sbarba, Z. Ivanovic and V. Praloran, Slowcycling/quiescence balance of hematopoietic stem cells is related to physiological gradient of oxygen, Exp Hematol 38, pp. 847-851.

Figure Legends.

Fig.1: Imaging the effect of biodiversity on tumor progression.

MRI follow up of tumor growth at day 30 and 60 after glioma cell implantation in the absence $(A, B)$ or presence $(C, D)$ of Dexter cells. For Dexter cell implantation, $5.10^{6}$ cells were implanted 30 days after glioma cells implantation. (E) Kaplan-Meier survival curves show a little increase in the survival of mice receiving a Dexter cell implantation and around the tumor mass (green line) compared to control mice implanted with glioma cells only (blue line) $(p<0.06$, log rank test).

\section{$\begin{array}{lll}\text { Day } 30 \text { Day } 60 & \text { Day } 30 & \text { Day } 60\end{array}$}

No Dexter cells implantation Dexter cells implantation

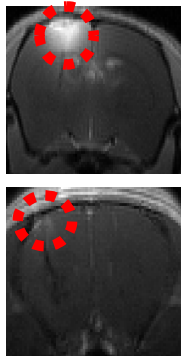

A

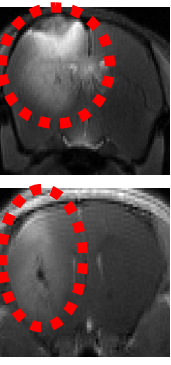

B

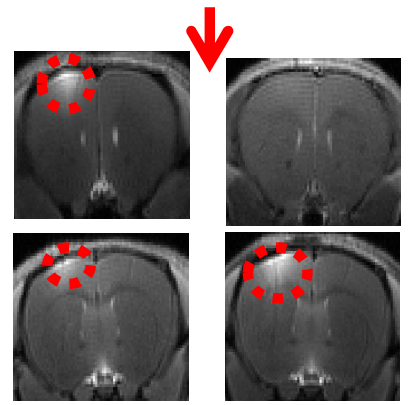

C

D

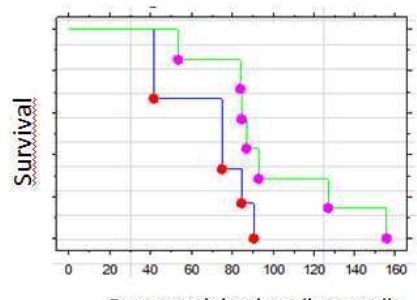

Days post injection glioma cells 